\title{
Bacterial colonization of suspended solids in the River Danube
}

\author{
Barbara Berger ${ }^{1}$, Birgit Hoch ${ }^{1}$, Gerhard Kavka ${ }^{2}$, Gerhard J. Herndl ${ }^{1, *}$ \\ ${ }^{1}$ Institute of Zoology, University of Vienna, Althanstr. 14, A-1090 Vienna, Austria \\ ${ }^{2}$ Federal Institute of Water Quality, Schiffmühlenstr. 120, A-1220 Vienna, Austria
}

\begin{abstract}
The River Danube was studied in the vicinity of Vienna (Austria) to examine the interactions among suspended matter, bacterial colonization and dissolved organic matter on a medium temporal and spatial scale. The concentration of suspended matter, the total number of particles and the number of bacteria attached to particles correlated with discharge rates. In the River Danube, $39 \%$ of the particles stained with Alcian Blue were colonized by bacteria, but only a small number of particles were heavily colonized. About $9.5 \%$ of the total bacterial community was found to be associated with particles; abundance of free-living bacteria varied between 2.4 and $7.8 \times 10^{6} \mathrm{cells} \mathrm{ml}^{-1}$ and attached bacterial abundance varied from 0.1 to $1.4 \times 10^{6} \mathrm{cells} \mathrm{ml}^{-1}$ On average, 8 bacteria particle ${ }^{-1}$ were found in the River Danube. Smaller particles were colonized more densely by bacteria than larger particles. In the River Danube, $60 \%$ of the particles were found to be in the size range of $>9$ to $100 \mathrm{\mu m}^{2}$ and $57 \%$ of the attached bacteria colonized this size class.
\end{abstract}

KEY WORDS: Danube $\cdot$ River $\cdot$ Bacteria $\cdot$ Particle $\cdot$ Suspended matter $\cdot$ Organic matter

\section{INTRODUCTION}

Bacteria play an important role in the trophic dynamics of aquatic food webs and in the remineralization of dissolved and particulate organic matter (Kirchman \& Mitchell 1982). The importance of freeliving versus particle-attached bacteria in these processes has been emphasized for several aquatic environments (Ducklow 1982, Hoppe 1984, Kondratieff \& Simmons 1985). From these studies some general conclusions can be drawn. First, it is obvious that only a small area of any given particle is usually colonized by bacteria (Hoppe 1984). Secondly, the proportion of bacteria attached to particles is usually $<10 \%$ of the total bacterial community (Kirchman \& Mitchell 1982) but can vary from a few $\%$ to $98 \%$ of total bacterial abundance in different aquatic regions (Iriberri et al. 1987). The large variations in the percentage of attached bacteria have been attributed to physical (such as turbidity, salinity, temperature, light, turbu-

-Addressee for correspondence.

E-mail: gerhard.herndl@univie.ac.at lence) and chemical characteristics (distribution of nutrients) of the water column (Palumbo et al. 1984, Kondratieff \& Simmons 1985, Almeida \& Alcantara 1992).

Most colonized particles (except flocculent aggregates) are sparsely colonized by bacteria (Kirchman 1983, Hoppe 1984). Obviously, the nature of particles and their adsorption capacities determine the magnitude of bacterial colonization (Hoppe 1984). Many particles and interfaces may not provide the conditions necessary for the successful competition of attached bacteria with bacteria in the water phase (Hoppe 1984).

High concentrations of suspended inorganic and organic particles are a characteristic feature of many large rivers (Findlay et al. 1991). Fluctuations in suspended matter influence several important biological and chemical processes in these systems. In rivers, for example, phytoplankton growth is often limited by light rather than nutrients (Kiss \& Genkal 1993, Kiss et al. 1994). Filter-feeding organisms can also be inhibited in their activity by high concentrations of suspended matter (Koenings et al. 1990). In the water col- 
umn, chemical processes are affected to a large extent by adsorption/desorption reactions of dissolved matter with parlicles (Baier et al. 1989, Weiss el al. 1991).

In this study we examined the influence of suspended solids on the bacterial community in the River Danube. We address the question of the distribution and flux of suspended solids and particulate and dissolved organic carbon in the River Danube in the vicinity of Vienna, Austria. Our aim is to elucidate the dynamics of free-living and attached bacteria and to determine the proportion of bacterially colonized particles in different size classes of the seston. Furthermore, we wanted to test whether the recently described particle class, the transparent polymer particles (Alldredge et al. 1993, Schuster \& Herndl 1995), is also present in river waters where concentrations of suspended clay are high and thereby potentially acting as an efficient sorption site. By combining a polysaccharide staining approach (Wiebe \& Pomeroy 1972, Kiørboe \& Hansen 1993, Passow \& Allredge 1994) with acridine orange and DAPI staining for bacterial enumeration, we examined the role of polysaccharides in providing colonizable surfaces for bacteria in a highly turbulent environment such as the River Danube.

\section{MATERIAL AND METHODS}

Sampling locations and procedure. Water samples were taken from the River Danube at its middle reach

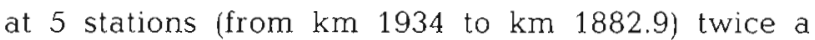
month between July and December 1993. One sampling site is situated upstream and 4 downstream of Vienna. In order to evaluate the impact of the sewage treatment of the City of Vienna, additional samples were collected from the Donaukanal, a channel of the backwater system in Vienna, into which the outlet of the waste water treatment plant flows. At each station, water was sampled from $0.2 \mathrm{~m}$ depth and filled into soaked (distilled water) and rinsed (water from the respective sampling location) plastic bottles. Temperature was measured during sampling. Water samples were stored in an insulated box in the dark for less than 3 h until further processing in the laboratory.

Enumeration of bacteria andi suspended soiidis. The abundance of free-living bacteria was determined using acridine orange- or 4',6-diamidino-2-phenylindole (DAPI) staining of bacteria and epifluorescence microscopy (Hobbie et al. 1977, Porter \& Feig 1980). Bacterial abundance was converted into carbon biomass assuming a carbon content of $20 \mathrm{fg} \mathrm{C} \mathrm{cell}^{-1}$ (Lee \& Fuhrman 1987).

Selected samples were double-stained with acridine orange and Alcian Blue to determine particle abundance and the percentage of bacteria attached to par- ticles (Alldredge et al. 1993, Schuster \& Herndl 1995). Alcian Blue is a specific stain for acidic mucopolysaccharides (Decho 1990). Size and abundance of particles were determined using light microscopy at $1250 x$ magnification. A volume of 1 to $3 \mathrm{ml}$ of sample was fixed with $0.2 \mu \mathrm{m}$ filtered formaldehyde (final conc. $2 \% ; \mathrm{v} / \mathrm{v}$ ) and stained with a few drops of an acridine orange solution $(0.2 \mu \mathrm{m}$ filtered). Subsequently, the stained sample was filtered onto a black polycarbonate filter (Millipore, pore size $0.2 \mu \mathrm{m}$ ) with a suction pressure of $<200$ mbar. While still under pressure, 100 to $200 \mu \mathrm{l}$ of a $0.2 \mu \mathrm{m}$ filtered aqueous solution of Alcian Blue $(0.2 \%, w / v$; in $0.6 \%$ acetic acid, $\mathrm{pH} 2.5)$ was added onto the wet filter and allowed to stain for $<5 \mathrm{~s}$ (Schuster \& Herndl 1995). The filter was embedded in paraffin oil and the abundance of particles and the percentage of bacteria attached to particles determined by switching between transmission and epiflunrescence microscopy. The size of the particles colonized by bacteria was measured directly using an ocular micrometer. The mean area of the colonized particles was calculated from the number of particles and the longest dimensions multiplied by the mean width of each particle. At least 20 particles were measured per sample (Schuster \& Herndl 1995).

Additional parameters. To determine dry weight (DW) and ash free dry weight (AFDW) of suspended matter, 200 to $400 \mathrm{ml}$ samples of river water were filtered through combusted and weighed Whatman GF/F filters. The filters were dried at $70^{\circ} \mathrm{C}$ overnight, weighed to determine DW of the total suspended matter and subsequently combusted at $450^{\circ} \mathrm{C}$ for $4 \mathrm{~h}$ and weighed again. AFDW was estimated from the weight loss upon ignition (Findlay et al. 1991). In order to convert $A F D W$ into $C$ equivalents it was assumed that $45 \%$ of the AFDW is particulate organic carbon (POC; Findlay et al. 1991).

The dynamics of water discharge rates, bacterial production derived from thymidine and leucine incorporation, chl a, dissolved (DOC) and total (TOC) organic carbon from the same sampling locations and period are reported elsewhere (Berger et al. in press). For comparison, POC was also calculated as the difference between TOC and DOC.

\section{RESULTS}

\section{Suspended particle dynamics}

In the River Danube and the Donaukanal, the number of particles exhibited a pronounced peak coinciding with high discharge rates in July and remaining fairly constant until the end of 1993 (Fig 1). Particles colonized by bacteria were predominantly flocculent. 
consisting of a polysaccharide (i.e. Alcian Blue stained) matrix, while clay particles were only rarely colonized. In the River Danube, the number of non-colonized and colonized particles varied between 0.2 and $3.5 \times 10^{5}$ and between 0.2 and $1.4 \times 10^{5}$ particles $\mathrm{ml}^{-1}$, respectively, with highest values found during the flood event (Fig. 1). On average, $39 \pm 11 \%$ (mean $\pm \mathrm{SD}, \mathrm{n}=60$ ) of all particles were colonized by bacteria. In the Donaukanal, the numbers of non-colonized and colonized particles varied between 0.1 and $1.2 \times 10^{5}$ and between 0.3 and $2.2 \times 10^{5}$ particles $\mathrm{ml}^{-1}$, respectively; on average, $47 \pm 9 \%(n=12)$ were colonized by bacteria.

The mean surface area of colonized particles was $43.0 \pm 76.9 \mu^{2}$ (mean $\pm S D$, range: 0.8 to $112.6 \mu \mathrm{m}^{2}, \mathrm{n}$ $=1578$ ) in the River Danube; non-colonized particles consisted mainly of single clay particles and were significantly smaller than the particles colonized by bacteria (Wilcoxon signed-ranks test: $p<0.001, n=24$ ). In the Donaukanal, the mean area of colonized particles was $64.0 \pm 146.6 \mu^{2}$ (range: 0.8 to $1854.4 \mu^{2}, \mathrm{n}=$ 290). The number of attached bacteria per unit particle area significantly decreased with increasing size of the particle at both sampling sites (River Danube and Donaukanal; Fig. 2). The number of particle-attached bacteria, however, significantly increased with increasing size of the particle both in the River Danube and the Donaukanal $(\mathrm{r}=0.637, \mathrm{n}=1578 ; \mathrm{r}=0.677, \mathrm{n}=$
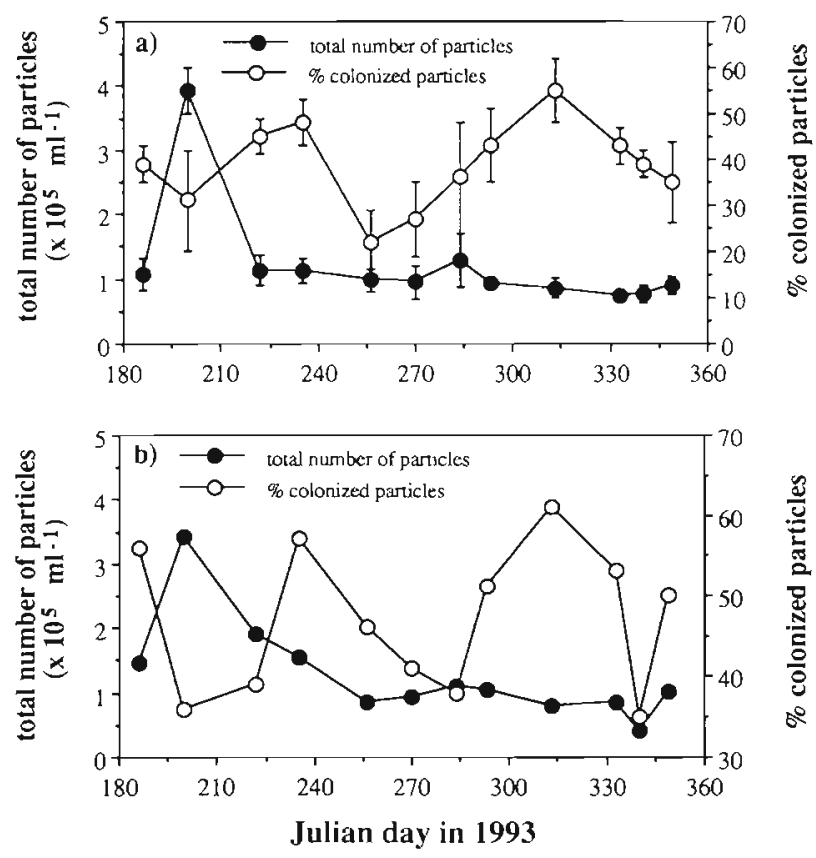

Fig. 1. Total number of particles and percentage of colonized particles in (a) the River Danube and (b) the Donaukanal between July and December 1993. For the River Danube, each dot represents the mean of 5 sampling locations; vertical $\mathrm{bar}=\mathrm{SD}$
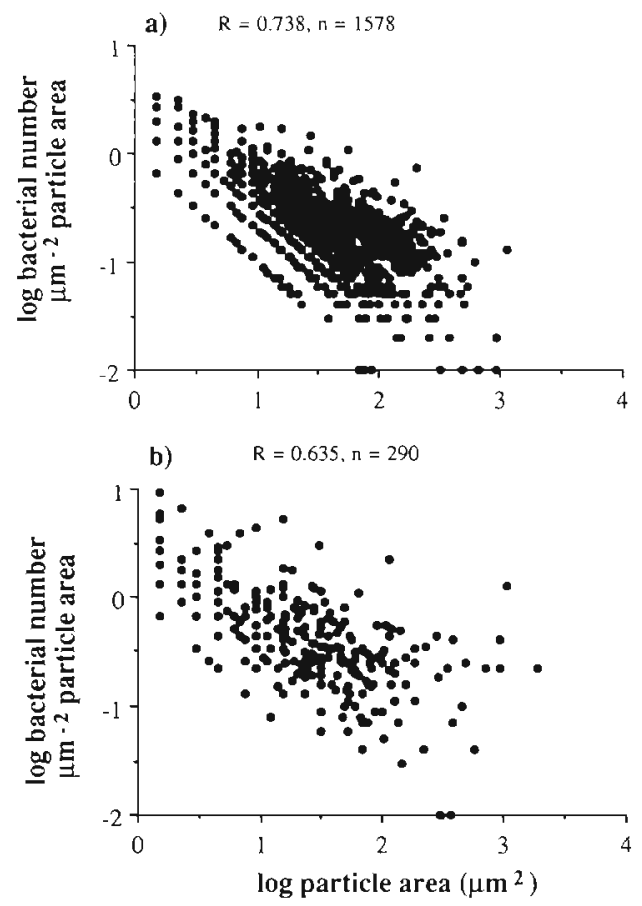

Fig. 2. Log-log plot of the relation between particle area and particle-attached bacteria $\mu \mathrm{m}^{-2}$ particle surface for (a) the

River Danube over all 5 stations and (b) the Donaukanal

290, respectively; Pearson correlation coefficient, $p<$ 0.001 ). The mean number of bacteria per particle was significantly higher in the Donaukanal (25 bacteria particle ${ }^{-1}$ ) than in the River Danube ( 8 bacteria parti$\mathrm{cle}^{-1}$; Wilcoxon test, $\mathrm{p}<0.001$ ). Also the number of bacteria per $\mu \mathrm{m}^{2}$ particle surface was significantly higher in the Donaukanal $\left(0.8\right.$ bacteria $\left.\mu \mathrm{m}^{-2}\right)$ than in the River Danube $\left(0.4\right.$ bacteria $\mu^{-2}$; Wilcoxon test, $\mathrm{p}<0.001$ ).

In order to investigate the bacterial colonization pattern in relation to particle size in more detail, the colonized particles were grouped into 3 size classes $(0.8$ to 9 , $>9$ to 100 and $>100$ to $1125 \mu^{2}$ ); the mean numbers of bacteria attached to particles of these size classes for the River Danube are shown in Table 1. The importance of particle size on the pattern of bacterial colonization was assessed in 2 ways: (1) via the relative frequency of each class of colonized particles (as a percentage of the total number of colonized particles) and (2) by the index of relative particle coverage (I) (Almeida \& Alcantara 1992). The index is the ratio in \% of the observed and the expected mean bacterial coverage; the expected mean coverage was calculated from the mean number of bacteria on the most densely colonized particles and multiplied by the surface area ratio of this size class (Table 1). Based on these calculations it is evident that for particles of the River Danube, bacterial colonization per unit area is only $16 \%$ of that of the most densely colonized particles (Table 1). Most 
Table 1. Contribution of colonized particles and bacteria attached to particles of different size classes to the total number of colonized particles and attached bacteria. Relative bacterial coverage of colonized particles in the River Danube and the Donaukanal: surface area ratio (SR, calculated by dividing the mean area of the 2 larger size classes, $>9$ to 100 and $>100$ to $1125 \mu \mathrm{m}^{2}$, by the mean area of the the smallest size class, $>0.8$ to $9 \mu \mathrm{m}^{2}$ ), average number of attached bacteria per particle (observed mean colonization, $n \pm S D$ ), theoretical number of bacteria per particle $(N$, calculated from the observed mean colonization of the smaller particles and SR) and the index of relative coverage $(I=100 \times \mathrm{n} / \mathrm{N}$, in $\%)$

\begin{tabular}{|c|c|c|c|c|c|c|}
\hline $\begin{array}{l}\text { Particle size } \\
\text { class }\left({\left.\mu m^{2}\right)}^{2}\right.\end{array}$ & $\begin{array}{l}\text { Fraction of all } \\
\text { colonized particles } \\
\text { (mean in } \% \text { ) }\end{array}$ & $\begin{array}{l}\text { Fraction of total } \\
\text { attached bacteria } \\
\text { (mean in \%) }\end{array}$ & $\mathrm{SR}$ & $\begin{array}{c}\text { Observed } \\
\text { colonization } \\
(n \pm S D)\end{array}$ & $\begin{array}{l}\text { Theoretical } \\
\text { colonization } \\
\text { (N) }\end{array}$ & $I(\%)$ \\
\hline \multicolumn{7}{|l|}{ River Danube } \\
\hline$>0.8$ to 9 & 29 & 10 & 1 & $2.8( \pm 1.7)$ & 2.8 & 100 \\
\hline$>9$ to 100 & 60 & 57 & 8 & $7.4( \pm 6.4)$ & 22.4 & 33 \\
\hline$>100$ to 1125 & 11 & 33 & 52 & $23.9( \pm 20.3)$ & 145.6 & 16 \\
\hline \multicolumn{7}{|l|}{ Donaukanal } \\
\hline$>0.8$ to 9 & 27 & 6 & 1 & $4.9( \pm 4.3)$ & 4.9 & 100 \\
\hline$>9$ to 100 & 60 & 34 & 8 & $12.5( \pm 12.5)$ & 39.2 & 32 \\
\hline$>100$ to 1125 & 13 & 60 & 84 & $105.7( \pm 222.1)$ & 411.6 & 26 \\
\hline
\end{tabular}

particles were found to be in the size class $>9$ to $100 \mathrm{\mu m}^{2}$, accounting for $60 \%$ of the total number of particles (Table 1) while the largest size class (>100 to $1125 \mu^{2}$ ) accounted for only $11 \%$ (Table 1 ). This distribution of size classes was also observed in the Donaukanal (Table 1). In the River Danube, $57 \%$ of the attached bacteria adhered to the $>9$ to $100 \mu^{2}$ size class; only $10 \%$ were associated with the smallest size class. In the Donaukanal, most particle-attached bacte-
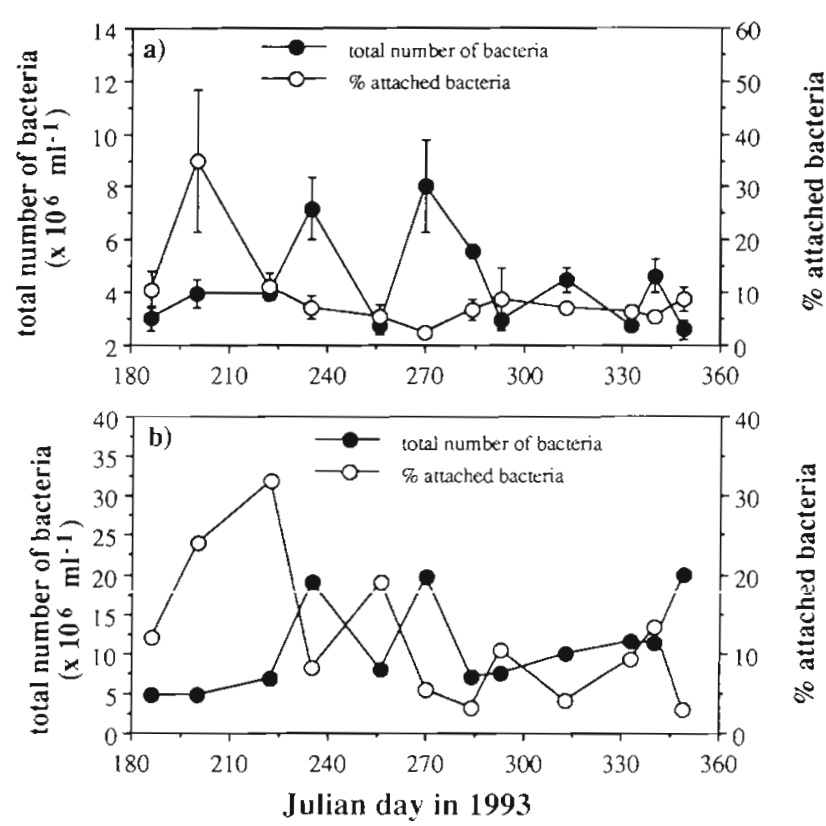

Fig. 3. Total number of bacteria and $\%$ attached bacteria of the total number of bacteria in (a) the River Danube and (b) the Donaukanal between July and December 1993. For the River Danube, each dot represents the mean of 5 sampling locations; vertical bar $=\mathrm{SD}$ ria $(60 \%)$ were associated with the $>100 \mu \mathrm{m}^{2}$ size class. At both sampling sites the smallest fraction of attached bacteria was found in the smallest particle fraction (Table 1).

\section{Fluctuations in bacterial abundance}

In the River Danube, total bacterial concentration fluctuated remarkably, with low values during the flood event (19 July, Day 200 and 10 August, Day 222) in the summer (Fig. 3). The dynamics in abundance of free-living and attached bacteria showed the same trends but the variations in free-living bacteria were not as pronounced. In the River Danube, the abundance of free-living bacteria varied between 2.4 and $7.8 \times 10^{6}$ cells $\mathrm{ml}^{-1}$; attached bacterial density varied from 0.1 to $1.4 \times 10^{6}$ cells $\mathrm{ml}^{-1}$ and was on average $9.5 \pm 8.3 \%$ of total bacterial density (Fig. 3). In the Donaukanal, attached and free-living bacteria showed a pattern similar to that in the River Danube. The abundance of free-living bacteria ranged from 3.6 to $19.3 \times 10^{6}$ cells $\mathrm{ml}^{-1}$, attached bacterial abundance varied from 0.2 to $2.2 \times 10^{6}$ cells $\mathrm{ml}^{-1}$ and accounted, on average, for $12 \pm 9 \%$ of total bacterial abundance.

\section{DOC and TOC concentrations}

In the River Danube, DOC concentrations ranged from 2.1 to $4.6 \mathrm{mg} \mathrm{Cl}^{-1}$ (mean: $3.3 \pm 0.6 \mathrm{mg} \mathrm{Cl}^{-1} ; \mathrm{n}=$ $60)$. The mean ( \pm SD) contribution of DOC to TOC was $82.2 \pm 15.3 \%(n=60)$. In the Donaukanal, DOC concentrations were $-5 \mathrm{mg} \mathrm{C} \mathrm{l}^{-1}$ with a single peak in November (17.3 $\mathrm{mg} \mathrm{C}^{-1}$ ), but followed otherwise the trend of the River Danube. 


\section{Spatial patterns of the measured microbial parameters}

The abundance of free-living and attached bacteria was significantly lower in the River Danube than in the Donaukanal (Wilcoxon test: $\mathrm{p}=0.001, \mathrm{p}=0.008$, respectively, $\mathrm{n}=12$; Table 2 ; data for the River Danube are mean values of the 5 sampling locations per sampling date). In the River Danube, no significant differences in bacterial abundance were found between sampling sites for free-living (Wilcoxon test: $p>0.05$ at least) or attached bacteria (Wilcoxon test: $p>0.08$ at least).

The abundance of both colonized and non-colonized particles, the mean area of colonized particles and the mean abundance of bacteria attached to particles did not vary among the sampling sites of the River Danube (Wilcoxon test: $\mathrm{p}>0.05, \mathrm{n}=12$ ). The abundance of colonized particles and mean abundance of bacteria attached to particles were significantly lower in the River Danube than in the Donaukanal (Wilcoxon test: $p<0.028, n=12$ ), whereas the abundance of non-colonized particles and the mean area of colonized particles were not significantly different (Wilcoxon test: $\mathrm{p}>$ $0.08, \mathrm{n}=12$; Table 2).

In the River Danube, the abundance of attached bacteria and both the colonized and non-colonized particles and the concentration of DW and AFDW of the suspended solids were positively correlated with water discharge ( $\mathrm{p}<0.001, \mathrm{n}=60$; Table 3). Dis-
Table 2. Comparison between the River Danube and the Donaukanal calculated by Wilcoxon signed-ranks test; abundance of free-living and attached bacteria, abundance of noncolonized and colonized particles, mean area of colonized particles, mean abundance of bacteria attached to particles, dry weight (DW) and ash free dry weight (AFDW). $p<0.05$

\begin{tabular}{|lcc|}
\hline Parameter & \multicolumn{2}{c|}{$\begin{array}{c}\text { Danube - Donaukanal } \\
\end{array}$} \\
& $\mathrm{p}$ & $\mathrm{N}$ \\
\hline Free-living bacteria & $<0.001^{\circ}$ & 12 \\
Attached bacteria & $<0.008^{\circ}$ & 12 \\
Non-colonized particles & $>0.08^{\circ}$ & 12 \\
Colonized particles & $<0.028^{\circ}$ & 12 \\
Mean area of colonized particles & $>0.08^{\circ}$ & 12 \\
Mean number of attached bacteria & $<0.007^{\circ}$ & 12 \\
DW & $>0.07$ & 12 \\
AFDW & $<0.006^{\circ}$ & 12 \\
& & \\
\hline
\end{tabular}

charge explained $70 \%$ of the variability of DW and abundance of non-colonized particles, whereas freeliving bacteria and DOC were not related to discharge. The \% AFDW of DW was negatively correlated with discharge $(\mathrm{r}=-0.520, \mathrm{n}=60, \mathrm{p}<0.001)$. In the Donaukanal only the abundance of non-colonized particles was highly significantly correlated with discharge ( $r=0.927, p<0.001, n=60$; Table 3 ). Attached particles and DW were significantly correlated, while the abundance of free-living and attached bacteria, AFDW and DOC were not related to discharge. As in the River Danube, the \% AFDW of DW was nega-

Table 3. Pearson's correlation matrix of the River Danube $(n=60)$ and the Donaukanal $(n=12)$. The correlation coefficient ( $r)$ was computed among the following parameters: discharge $\left(\mathrm{m}^{3} \mathrm{~s}^{-1}\right)$, abundance of non-colonized particles ml ${ }^{-1}$ (non-col. part.) and colonized particles $\mathrm{ml}^{-1}$ (col. part.), concentration of dry weight (DW, $\mathrm{mg} \mathrm{l}^{-1}$ ) and ash free dry weight (AFDW, mg l-1), abundance of free bacteria (free BA, cells $\mathrm{ml}^{-1}$ ), abundance of attached bacteria (att. BA, cells $\mathrm{ml}^{-1}$ ) and concentration of dissolved organic carbon (DOC, $\left.\mathrm{mg} \mathrm{l}^{-1}\right)$; $\cdot \mathrm{p}<0.001$; ns: not significant

\begin{tabular}{|c|c|c|c|c|c|c|c|c|}
\hline & Discharge & Non-col part. & Col part. & DW & AFDW & Free BA & Att. BA & DOC \\
\hline \multicolumn{9}{|l|}{ River Danube } \\
\hline Discharge & 1 & & & & & & & \\
\hline Non-col. part. & $0.822^{\circ}$ & 1 & & & & & & \\
\hline Col. part. & $0.642^{\circ}$ & $0.613^{\circ}$ & 1 & & & & & \\
\hline DW & $0.845^{\circ}$ & $0.605^{\circ}$ & $0.659^{\circ}$ & 1 & & & & \\
\hline AFDW & $0.770^{\circ}$ & $0.572^{\circ}$ & $0.570^{\circ}$ & $0.773^{\circ}$ & 1 & & & \\
\hline Free BA & ns & ns & $\mathrm{ns}$ & ns & ns & 1 & & \\
\hline Att. BA & $0.687^{\circ}$ & $0.613^{\circ}$ & $0.944^{\circ}$ & $0.652^{\circ}$ & $0.624^{\circ}$ & ns & 1 & \\
\hline DOC & ns & ns & ns & ns & ns & -0.304 & ns & 1 \\
\hline \multicolumn{9}{|l|}{ Donaukanal } \\
\hline Discharge & 1 & & & & & & & \\
\hline Non-col. part. & $0.927^{\circ}$ & 1 & & & & & & \\
\hline Col, part. & 0.719 & $0.825^{\circ}$ & 1 & & & & & \\
\hline DW & 0.561 & 0.641 & 0.632 & 1 & & & & \\
\hline AFDW & ns & ns & ns & ns & 1 & & & \\
\hline Free BA & ns & ns & ns & ns & ns & 1 & & \\
\hline Att. BA & ns & ns & ns & ns & ns & ns & 1 & \\
\hline $\mathrm{DOC}$ & ns & ns & ns & ns & ns & ns & ns & 1 \\
\hline
\end{tabular}


tively correlated with discharge $(r=-0.574, n=60$, $\mathrm{p}<0.05$ ).

DW and AFDW were highly correlated with attached bacteria, non-colonized and colonized particles in the River Danube ( $p<0.001$; Table 3$)$. In the Donaukanal, DW was correlated with the abundance of both noncolonized and colonized particles $(\mathrm{p}<0.02, \mathrm{n}=12$; Table 3). AFDW was significantly correlated with DW in the River Danube ( $p<0.001$; Table 3 ) but not in the Donaukanal. In the River Danube, both non-colonized and colonized particles were significantly positively correlated with the number of attached bacteria $(\mathrm{p}<$ 0.001 ; Table 3 ); however, this relationship was not detectable in the Donaukanal.

\section{DISCUSSION}

The combination of high water discharge and high suspended matter concentrations in rivers is responsible for the transfer of suspended matter from the terrestrial environment to the ocean (Milliman \& Meade 1983, Degens \& Ittekkot 1985, Ellsworth 1986, Ittekkot 1988, Findlay et al. 1991). We examined the interactions between suspended matter and physical and biological processes on a medium temporal and spatial scale along a stretch of the River Danube near Vienna. At an annual mean discharge rate of $1843 \mathrm{~m}^{3} \mathrm{~s}^{-1}$ (Berger et al. in press) and a suspended matter concentration of $24 \mathrm{mg} \mathrm{l}^{-1}$ (this study), the River Danube transports about $1.3 \times 10^{6} \mathrm{t} \mathrm{yr}^{-1}$ of suspended matter from Austria to lower stretches; for comparison, the

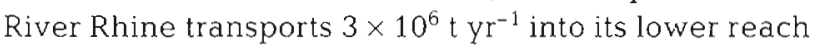
(Admiraal \& Zanten 1988).

The number of bacteria attached to particles was determined by counting the number of bacteria per particle and the number of particles per working field with a light microscope. Using this procedure for counting particle-bound bacteria, their abundance is underestimated by about $45 \%$ because of bacteria possibly inside or underneath the particles (Kirchman et al. 1982). Bacterial colonization of particles varied considerably in our study, ranging from 3 to 17 bacteria particle ${ }^{-1}$ (mean $\pm S D=8 \pm 3$ bacteria particle ${ }^{-1}$ ), which

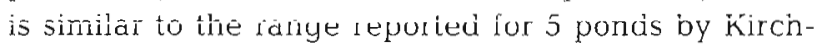
man \& Mitchell (1982) and for other aquatic systems (Hoppe 1984). In comparison to other riverine systems, however, the mean percentage of attached bacteria is rather low in the River Danube (Fig. 3). In the River Elbe (Germany), for example, attached bacteria varied between 14 and 51\% (Zimmermann 1975). The relatively low \% observed in the River Danube (Fig. 3) probably reflects the high proportion of inorganic constituents in the total concentration of suspended matter, especially during times of high discharge. The sea- sonal changes in attached bacteria might be regulated by the supply of colonizable particles. In degradation experiments, Hoch el al. (1995) found that the bacterial community plays a crucial role in the decomposition and decay of the non-living organic particles in the River Danube, although, on average, only $9.5 \%$ were found attached to particles. In these degradation experiments the number of particles decreased by up to $50 \%$ during the incubation period of $5 \mathrm{~d}$. The contribution of attached bacteria to the total bacterial community can vary from $<10$ to $94 \%$ depending on particle abundance and composition and nutrient conditions in the water phase (Hoppe 1984); commonly about $10 \%$ of the bacteria are attached to surfaces (Hoppe 1984).

In the River Danube, $39 \%$ of the suspended particles were colonized by bacteria. In coastal and estuarine waters about $50 \%$ of the particles are free of bacteria and only a small number of particles are heavily colonized (Hoppe 1984). This colonization pattern was also observed in the River Danube; moreover, the percentage of particles colonized by bacteria was high when the total number of particles was low (Fig. 1). In contrast to free-living bacteria, attached bacteria vary in abundance over a wide range. In the River Danube, the abundance of particle-bound bacteria varied by a factor of 14 , whereas free-living bacteria varied only by a factor of 3 in the Donaukanal, the corresponding variations were 11 and 5 times, respectively. Our range of variation is small compared to other freshwater systems; the abundance of particle-bound bacteria varied by a factor of 1000 and free-living bacteria by a factor of 2 in a pond (Kirchman 1983). In the River Danube, free-living and attached bacterial densities are well within the range observed for other rivers. In the Dan River in Virginia (USA), Kondratieff \& Simmons (1985) reported a variation in bacterial abundance by a factor of 13 for particle-bound bacteria and a factor of 2 for free-living bacteria; in the York River estuary, Virginia, Ducklow (1982) obtained a 3- and 7-fold variation, respectively. In the Rhine River, free-living bacteria varied by a factor of 8 (De Ruyter van Steveninck et al. 1992).

In the River Danube, colonized particles were on average $13 \mu \mathrm{m}$ in diameter, while in the Donaukanal mean particle diameter was $16 \mu m_{i}$ similar diameters were found for suspended solids in the Ogeechee River, USA (Carlough 1994). Studies in different aquatic systems indicate that with decreasing particle size, microbial biomass and activity increases (Wallace et al. 1982, Kondratieff \& Simmons 1985, Almeida \& Alcantara 1992). In the River Danube, smaller particles exhibited higher bacterial abundances per unit surface area than larger particles (Table 1, Fig. 2a); in the Donaukanal we found a similar relationship (Fig. 2b). 
A similar relation between colonization density and particle size was recently detected by Passow \& Alldredge (1994) and Schuster \& Herndl (1995).

In this study, the POC concentration can be derived in 2 different ways: (1) using the conversion factor of Findlay et al. (1991) to calculate POC concentrations from the AFDW (i.e. $\mathrm{POC}=45 \%$ of $\mathrm{AFDW}$ ) and (2) from the difference between TOC and DOC. In the River Danube and the Donaukanal, POC concentrations calculated from AFDW are significantly higher (3 and 1.5 times, respectively) than the POC concentration based on TOC and DOC (Wilcoxon test: $p<0.001$, $\mathrm{n}=58$, and $\mathrm{p}<0.01, \mathrm{n}=12$, respectively). One possible explanation for this discrepancy might be that the carbon fraction of the AFDW is lower than assumed or that filtering water through Whatman GF/F filters may cause release of intracellular products from phytoplankton leading to elevated DOC concentrations. On the other hand, rapidly sinking particles could have been excluded from the TOC analyses since only a small portion of the water $(100 \mu l)$ was injected into the TOC analyzer. For the following calculations, the higher POC estimates based on the conversion of AFDW into POC equivalents are used.

In the River Danube, phytoplankton contribution to POC was roughly $9.2 \pm 8.2 \%$ (assuming a C:chl a ratio of 30; Banse 1977), bacteria contributed $3.9 \pm 2.5 \%$ (assuming a bacterial C content of $20 \mathrm{fg}$ cell $^{-1}$; Lee \& Fuhrman 1987) and flagellates $0.2 \pm 0.2 \%$ (assuming $220 \mathrm{fg} \mathrm{C} \mu \mathrm{m}^{3}$; Børsheim \& Bratbak 1987, data not shown). Following the low phytoplankton biomass in the summer, 2 peaks were detectable in late August and September when a pronounced phytoplankton bloom occurred. Thereafter, the contribution of phytoplankton to riverine $\mathrm{POC}$ decreased continuously until the end of the year. Bacterial biomass exhibited similar fluctuations. In the Donaukanal, the contribution of organisms to the POC load was slightly lower than in the River Danube.

In summary, we have shown that in the River Danube high densities of particles were detectable during periods of high water discharge. Particle concentration correlated with DW and AFDW and the number of bacteria attached to particles, exhibiting pronounced peaks during the flood period in July. In the River Danube, $39 \%$ of the particles were colonized by bacteria but only a small number of particles were heavily colonized. In comparison to other riverine systems the mean percentage of attached bacteria was rather low. Non-colonized particles consisted mainly of single clay particles and were significantly smaller than the particles colonized by bacteria. The number of attached bacteria per unit particle area decreased significantly with increasing size of the particle, whereas the total number of bacteria per particle increased with increasing size of the particle.
Acknowledgements. We thank the staff of the Federal Institute for Water Quality for their invaluable assistance during field and laboratory work. Financial support was provided by the Austrian National Bank (project \# 4506) and the Austrian Science Foundation (FWF grant \# 8608). The work is in partial fulfilment of the requirements towards a Ph.D. degree at the University of Vienna by B.B.

\section{LITERATURE CITED}

Admiraal W, Zanten BV (1988) Impact of biological activity on detritus transported in the lower River Rhine: an exercise in ecosystem analysis. Freshwat Biol 20:215-225

Alldredge AL, Passow U, Logan BE (1993) The abundance and significance of a class of large, transparent organic particles in the ocean. Deep Sea Res I 40:1131-1140

Almeida MA, Alcantara F (1992) Bacterial colonization of seston particles in brackish waters (Ria de Aveiro, Portugal). Mar Ecol Prog Ser 89:165-173

Baier RW, Cucci TL, Yentsch CM (1989) Flow cytometry for observing the distribution of adsorption sites on particles. Limnol Oceanogr 34:947-952

Banse K (1977) Determining the carbon-to-chlorophyll ratio of natural phytoplankton. Mar Biol 41:199-212

Berger B, Hoch BM, Kavka G, Herndl GJ (in press) Bacterial metabolism in the River Danube: parameters influencing bacterial production. Freshwat Biol

Børsheim KY, Bratbak G (1987) Cell volume to cell carbon conversion factors for a bacterivorous Monas sp. enriched from seawater. Mar Ecol Prog Ser 36:171-175

Carlough LA (1994) Origins, structure and trophic significance of amorphous seston in a blackwater river. Freshwat Biol 13:227-231

Decho AW (1990) Microbial exopolymer secretions in ocean environments: their role(s) in food webs and marine processes. Oceanogr Mar Biol A Rev 28:73-153

Degens ET, lttekkot V (1985) Particulate organic carbon: an overview. Mitt Geol-Paläontol Inst Univ Hamburg SCOPE-UNEP Sonderbd 58:7-27

De Ruyter van Steveninck ED, Admiraal W, Breebaart L, Tubbing GMJ, Zanten BV (1992) Plankton in the River Rhine: structural and functional changes observed during downstream transport. J Plankton Res 14:1351-1368

Ducklow HW (1982) Chesapeake Bay nutrient and plankton dynamics. 1. Bacterial biomass during spring tidal destratification in the York River, Virginia, estuary. Limnol Oceanogr 27:651-659

Ellsworth JM (1986) Sources and sinks for fine-grained sediment in the lower Hudson River. Northeast Geol 8: $141-155$

Findlay S, Pace M, Lints D (1991) Variability and transport of suspended sediment, particulate and dissolved organic carbon in the tidal freshwater Hudson River. Biogeochemistry 12:149-169

Hobbie JE, Daley RJ, Jasper S (1977) Use of Nuclepore filters for counting bacteria by epifluorescence microscopy. Appl Environ Micrabiol 33:1225-1228

Hoch BM, Berger B, Kavka G, Herndl GJ (1995) Remineralization of organic matter and degradation of the organic fraction of suspended solids in the River Danube. Aquat Microb Ecol 9:279-288

Hoppe HG (1984) Attachment of bacteria: advantage or disadvantage for survival in the aquatic environment. In: Marshall KC (ed) Microbial adhesion and aggregation. Springer, Berlin, p 283-301

Iriberri J, Unanue M, Barcina I, Egia L (1987) Seasonâl varia- 
tion in population density and heterotrophic activity of attached and free-living bacteria in coastal waters. Appl Environ Microbiol 53:2308-2314

Ittekkot $V$ (1988) Global trends in the nature of organic matter in river suspensions. Nature 332:436-438

Kiorboe T, Hansen JLS (1993) Phytoplankton aggregate formation: observations of patterns and mechanisms of cell sticking and the significance of exopolymeric material. J Plankton Res 15:993-1018

Kirchman D (1983) The production of bacteria attached to particles suspended in a treshwater pond. Limnol Oceanogr 28:858-872

Kirchman D, Ducklow H, Mitchell R (1982) Estimates of bacterial growth from changes in uptake rates and biomass. Appl Environ Microbiol 44:1296-1307

Kirchman D, Mitchell R (1982) Contribution of particle-bound bacteria to total microheterotrophic activity in five ponds and two marshes. Appl Environ Microbiol 43:200-209

Kiss KT, Àcs É, Kovács A (1994) Ecological observations on Skeletonema potamos (Weber) Hasle in the River Danube, near Budapest (1991-92, daily investigations). Hydrobiologia 289:163-170

Kiss KT, Genkal SI (1993) Winter blooms of centric diatoms in the River Danube and its side-arms near Budapest (Hungary). Hydrobiologia 269/270:317-325

Koenings JP, Burkett RD, Edmundson J (1990) The exclusion of limnetic Cladocera from a turbid glacier-meltwater lake. Ecology 71:57-67

Kondratieff PF, Simmons GM (1985) Microbial colonization of seston and free bacteria in an impounded river. Hydrobiologia 128:127-133

Responsible Subject Editor: J. Dolan, Villefranche-sur-Mer, France
Lee S, Fuhrman JA (1987) Relationships between biovolume and biomass of naturally derived marine bacterioplankton. Appl Environ Microbiol 5.3:1298-1303

Milliman DJ, Meade RH (1983) World-wide delivery of river sediment to the oceans. J Geol 91:1-21

Palumbo AV, Ferguson RL, Rublee PA (1984) Size of suspended bacterial cells and association of heterotrophic activity with size fractions of particles in estuarine and coastal waters. Appl Environ Microbiol 48:157-164

Passow U, Alldredge AL (1994) Distribution, size and bacterial colonization of transparent exopolymer particles (TEP) in the ocean. Mar Ecol Prog Ser 113:185-198

Porter KG, Feig YS (1980) The use of DAPI for identifying and counting aquatic microflora. Limnol Oceanogr 25:943-948

Schuster S, Herndl GJ (1995) Formation and significance of transparent exopolymeric particles in the northern Adriatic Sea. Mar Ecol Prog Ser 124:227-236

Wallace JB, Ross DH, Meyer JL (1982) Seston and dissolved organic carbon dynamics in a southern Appalachian stream. Ecology 63:824-838

Weiss H, Koide M, Bertine KK, Goldberg ED (1991) Scavenging of particulate matter in coastal waters. Mar Chem $32: 171-175$

Wiebe WJ, Pomeroy LR (1972) Microorganisms and their association with aggregates and detritus in the sea: a microscopic study. Mem Inst Ital Idrobiol (Suppl) 29: $325-352$

Zimmermann R (1975) Entwicklung und Anwendung von fluoreszenz- und rasterelektronenmikroskopischen Methoden zur Entwicklung in Wasserproben. PhD thesis, Univ Kiel

Manuscript first received: May 30, 1995

Revised version accepted: November 20, 1995 